\title{
The Dual Mandate: Has the Fed Changed Its Objective?
}

\author{
Daniel L. Thornton
}

\begin{abstract}
The Federal Reserve is said to have a dual mandate of price stability and full employment. While the Fed has mentioned price stability as one of its primary goals, it has been reluctant to mention employment as a separate policy objective, preferring instead to state that maximum employment could best be achieved by achieving price stability. This hesitance ended with the December 2008 policy directive in which the Federal Open Market Committee (FOMC) noted its objectives were "maximum employment and price stability." Operationally equivalent language first appeared in the FOMC's policy statement in September 2010 and has appeared in every subsequent statement. This article reviews the FOMC transcripts and biannual statements to Congress to provide some insight into the Fed's historical reluctance to mention employment as an independent policy objective. The FOMC documents do not point to a specific reason for the historical reluctance, but they provide a few clues. Perhaps more importantly, they point to two changes that may explain the recent change in language: the increased emphasis on economic stabilization and the shift in emphasis from the growth rate of output to the level of output.
\end{abstract} (JEL E52, E58)

Federal Reserve Bank of St. Louis Review, March/April 2012, 94(2), pp. 117-33.

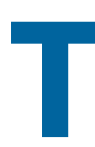

he Full Employment and Balanced Growth Act of 1978, more commonly known as the Humphrey-Hawkins Act (henceforth, HH), established price stability and full employment as national economic policy objectives. The act is said to establish a dual mandate for the Federal Reserve of maximum employment and price stability. 1 Elsewhere (Thornton, 2011a) I noted that despite HH's requirements, until recently the Federal Open Market Committee (FOMC) had been cautious not to state its policy objectives in terms of either full employment or the unemployment rate, preferring instead to state its dual mandate in terms of price stability and economic growth.

Specifically, my review of FOMC policy directives from August 1979 reveals that the FOMC made no reference to employment in its policy directives until December 2008. Several possible reasons may explain the Committee's reluctance to state an objective for employment growth or the unemployment rate. For example, while policymakers generally agree that their policy actions

Daniel L. Thornton is a vice president and economist at the Federal Reserve Bank of St. Louis. The author thanks Bryan Noeth, Hoda El-Ghazaly, and Mingyu Chen for valuable research assistance.

(c) 2012, The Federal Reserve Bank of St. Louis. The views expressed in this article are those of the author(s) and do not necessarily reflect the views of the Federal Reserve System, the Board of Governors, or the regional Federal Reserve Banks. Articles may be reprinted, reproduced, published, distributed, displayed, and transmitted in their entirety if copyright notice, author name(s), and full citation are included. Abstracts, synopses, and other derivative works may be made only with prior written permission of the Federal Reserve Bank of St. Louis. 


\section{Thornton}

have a direct effect on economic growth through their effect on interest rates and/or the growth of monetary and credit aggregates, there may be less agreement on how the effect of policy actions on economic growth translates into employment growth or the unemployment rate. And while economic growth has been historically related to employment through what is called Okun's law (1962), the effect is neither as direct nor as predictable as the effect on economic growth (see, e.g., Knotek, 2007, and Daly and Hobijn, 2010).

Policymakers might also be reluctant because both Friedman (1968) and Phelps (1968) demonstrated that the equilibrium unemployment rate cannot be permanently affected by monetary policy (the natural rate hypothesis). Specifically, policymakers may be reluctant to state policy objectives in terms of a variable that they cannot affect in the long run.

Finally, the equilibrium unemployment rate can change for reasons unrelated to the macroeconomy (i.e., governmental policies, institutional structure, and a variety of other factors) and hence cannot be affected by central bank monetary policies. $\underline{2}$ Consequently, policymakers' reluctance to set a numerical objective for the unemployment rate is understandable given concern that they might not be able to achieve it.

This paper extends my previous work by reviewing the transcripts of FOMC meetings for the period 1978-2005 and the congressional testimony of the Fed Chairmen from 1978 through February 2011. My objective is to investigate why policymakers chose not to state their policy objective in terms of employment growth or the unemployment rate despite their awareness that this objective was part of their legal mandate. The methodology is that of Meade and Thornton (2011). Specifically, 27 years of FOMC transcripts and 33 years of congressional testimony by Fed officials were searched electronically to find FOMC discussions of either the dual mandate or employment or the unemployment rate as an objective of policy. The search used seven keywords: employment, dual, mandate, Humphrey, objective, goal, and target. All sections of these documents containing the keywords were read to determine whether the discussion regarded the dual mandate or some measure of employment as an objective of policy. The search yielded many discussions of employment that were unrelated to policy goals, but surprisingly few about the dual mandate or employment or unemployment as a policy objective. Thus, despite the keyword search procedure, a considerable amount of time was spent reading large sections of the transcript.

With the exception of Chairman Alan Greenspan's reaction to Governor Edward Gramlich's suggestion in late 2003 that the policy statement include the phrase "maximum sustainable employment," no one explicitly suggested that targeting employment or the unemployment rate might be more than monetary policy was capable of achieving. While numerous Committee participants suggested some of the requirements of $\mathrm{HH}$ were "onerous" or "troubling," none specifically mentioned what the onerous or troubling aspects of the act were. Nevertheless, Committee members seemed to understand what these vague references meant without asking for clarification. At some point or other, virtually every participant acknowledged that inflation is the only thing the Fed can control in the long run. Hence, there appears to have been widely shared agreement that monetary policy cannot affect employment, the unemployment rate, or economic growth in the long run. However, no one explicitly stated this as a reason for not mentioning employment growth or the unemployment rate in the policy statement.

What emerges from the transcripts and testimony, however, is an increased desire to engage in more economic stabilization as inflation reached more acceptable levels and policymakers 
became increasingly confident that inflation would remain relatively low and stable. This change occurred almost simultaneously with an increase in the number of academic economists on the Committee.

The remainer of the paper summarizes all discussions of employment or the unemployment rate in the context of the dual mandate. This summary quotes liberally from the original text to provide a fuller account of the FOMC's discussions of employment and the unemployment rate in that context.

\section{POLICYMAKERS' VIEW OF THE DUAL MANDATE: THE FOMC TRANSCRIPTS}

The issue of the dual mandate arose at the March 1978 FOMC meeting before the passage of HH. In response to Governor Henry Wallich's observation that unemployment was currently 6.1 percent, noting that he viewed full employment to be about 5.5 percent to 6 percent, thenVice Chairman Paul Volcker noted that there were difficulties associated with the then-pending HH legislation:

I was also struck, in terms of potential problems for the Federal Reserve, which have been [alluded] to in a couple of different ways by what Governor Wallich said about time for a slow landing and all this nomenclature that we have full employment someplace in the 5 to 6 percent or 5-1/2 to 6 percent area. That gets into the Humphrey-Hawkins bill. [Let's assume] we get the passage of the current congressional package on the Humphrey-Hawkins bill. If Henry is right, and there is a good deal in what he says, how does one go up there and testify how we are on the path and conducting policies toward whatever figure they have in there for Humphrey-Hawkins? [It] is not very far off. It seems to me that we are in a very awkward position. I don't know whether that bill is absolutely going to pass. It's very hard to oppose it. But the awkwardness of our position struck me, as I heard Governor Wallich speak..,$\underline{5}$

Volcker's remarks were followed by an interesting discussion:

MR. WALLICH. If you contemplate what Humphrey-Hawkins implies, if anybody abroad thought this would be taken seriously, we would be disavowing all our anti-inflation effort.

VICE CHAIRMAN VOLCKER. Well, I agree with that. But what position are we put in by this bill when we have to go up there and in effect say that our policies are-

CHAIRMAN MILLER. We'll have to find an ingenious way to [indicate] that our policies are taking account of the other parts [of the legislation]. We also have to work toward price stability and fight inflation.

President John Balles of the San Francisco Fed offered a solution to the problem. Specifically, he noted that "inflation does cause recession, and recession causes high unemployment. Therefore, if you want to avoid high unemployment, you avoid high inflation. High inflation, high interest rates, and high unemployment go together and vice versa." 6 In effect, he suggested that the FOMC could argue that they were promoting low unemployment by pursuing price stability. This became a common explanation of how the FOMC fulfilled its dual mandate-by pursuing price stability, it was simultaneously pursuing maximum sustainable employment. 


\section{Thornton}

After the passage of $\mathrm{HH}$, most Committee discussion focused on the biannual reporting requirements of the new law. There was little discussion of the dual mandate. At the December 1978 meeting, Governor Nancy Teeters steered the discussion toward the dual mandate by noting that setting a growth rate objective for money and credit aggregates, as required by $\mathrm{HH}$, was too narrow:

I feel very strongly that the object of policy should be toward [achieving] what I consider to be the ultimate goals for policy, mainly output, employment, and prices-and one that we have no control over, which is an acceptable distribution of income. I feel that money is really one of the tools and not the end of the policy and that we should start moving toward focusing the policymaking on our ultimate objectives rather than on an intermediate, in-between type of objective. And it seems to me that one of the major objectives of the Full Employment [and Balanced Growth] HumphreyHawkins Act was basically to improve public understanding of economic policymaking and to lay out what it is we want to accomplish rather than to get ourselves hung up on M1 or M2 or something of the sort. $?$

While there was some discussion of the unemployment rate and various members discussed their view of whether the economy was at or near full employment, there was no explicit discussion of maximum employment, full employment, or the unemployment rate as a policy objective until a decade later.

At the February 9-10, 1988, meeting, President W. Lee Hoskins of the Cleveland Fed questioned Board staffer Mike Prell about a statement in a staff report, which Hoskins characterized as suggesting that "we \{the FOMC\} want maximum output without a significant acceleration in inflation." Hoskins went on to say "One could reverse that and say we want to achieve a deceleration in inflation without significantly damaging employment and output. Did you choose that assumption or are we to discuss that assumption?" Governor Wayne Angell responded to Hoskins's comment, noting "the way you \{Hoskins\} stated it is somewhat different than it's written...The way it's written is so contrary to everything I believe about what our job is, that it causes me to wonder: Have I missed something all these two years or have we had this stated before?" The staff's statement read

Rather, we worked from what we took to be the fundamental objectives behind the Committee's actions for some time now. First, we assumed that policy would be aimed at accommodating such growth as would be possible without creating pressures that would produce a substantial pickup in inflation.

President Gary Stern of the Minneapolis Fed brought up the issue of the FOMC's policy objective on the second day of the meeting, noting that

However we may decide to tilt policy in the short run, it seems to me that in the longer term we have to keep our eye on the price stability goal. And I think achievement of that is consistent with some of Mike Prell's language that we touched upon yesterday; in other words, I think that's how you do achieve maximum sustainable growth in employment and output.

There appeared to be nearly unanimous agreement among Committee members that price stability was the primary goal of policy, not for its own sake but because by pursuing this goal, policymakers simultaneously achieved the goal of maximum sustainable economic growth and, 
consequently, maximum sustainable employment. Hence, the FOMC appears to believe it could achieve the employment aspect of HH's dual mandate by its price stability objective, just as President Balles had suggested a decade earlier.

Nevertheless, opinion sometimes differed about the extent to which policy should focus on inflation or output growth and employment in the short run. Some members expressed concern that reducing inflation too quickly could be politically unacceptable. For example, at the July 5-6, 1989, meeting, Governor Martha Seger expressed a desire for an easier policy, saying

probably there are a thousand people in the country who know what we do at the FOMC...But there are 500 and some people down at the other end of Constitution Avenue who are going to be following what goes on in the real economy. If the economy weakens even further and they start hearing from the folks at home about rising unemployment rates and so forth, then I'm sure our Chairman here is not going to be the man of the hour when he has to go down there and meet with thembecause I think they will wonder why we didn't see what was going on, or if we saw it, why we ignored it and didn't react.

President Edward Boehne of the Philadelphia Fed framed the issue somewhat differently, saying

to say that our objective is price stability greatly oversimplifies what a central bank is all about. It seems to me that what the central bank is all about is sustainable prosperity. Over the longer pull, probably the most important contribution that we can make to that is price stability. But that to me is a means to an end, not an end in itself. So, in terms of sending out signals, I think that our signal ought to be one that says we are trying to have a sustainable prosperity.

A number of prominent academic economists became members of the FOMC in the 1990s, most notably Janet Yellen, Laurence Meyer, and Alan Blinder. Meade and Thornton (2011) show that these members contributed significantly to the marked increase in the number of mentions of the Phillips curve and the nonaccelerating inflation rate of unemployment during the 1990s. This change in the composition of the FOMC was reflected in discussions of the Fed's dual mandate.

The first major discussion of the dual mandate occurred at the first FOMC meeting in 1995 during a planned debate between President Yellen of the San Francisco Fed and President Alfred Broaddus Jr. of the Richmond Fed on the pros and cons of the FOMC adopting a formal numerical inflation objective. At one point during the discussion, President Robert Forrestal of the Atlanta Fed expressed the view that adopting an inflation target would give the Committee a longer-term focus, suggesting that the Committee's focus had been too shortsighted. In contrast, Governor Blinder argued that the Committee had a dual mandate, suggesting that there is a short-run trade-off between inflation and employment or output growth and that "There is no existing evidence-and I can't say this too strongly - that having such targets leads to a superior trade-off." Blinder was echoing one of President Yellen's debating points-namely, that "when the goals conflict... a wise and humane policy is occasionally to let inflation rise even when inflation is running above target." 8 Both Blinder and Yellen embraced the natural rate hypothesis but argued against the idea that the best way to achieve maximum sustainable output, and hence employment, is to simply stabilize prices. 


\section{Thornton}

The best discussion of individual members' views about the full employment aspect of the Fed's dual mandate occurred several months later during a discussion of legislation proposed by Senator Connie Mack-the Economic Growth and Price Stability Act of 1995. Chairman Greenspan initiated the discussion by saying that he would likely be called on to present the Committee's views on this legislation and that it would therefore be useful to get the Committee's views.

President Robert Parry of the San Francisco Fed suggested that overall the "Mack bill would be a big improvement on Humphrey-Hawkins," in that it would clarify the Committee's goals and "place the primary emphasis on price stability." ${ }^{-}$He endorsed the idea of an explicit numerical inflation objective, indicating that it might improve the public's understanding of policy and increase the FOMC's credibility.

President Broaddus also supported the legislation and argued that there are "limits to the Fed's ability to pursue a price stability objective in the current institutional environment under current law." He expressed doubt that the Committee could achieve "full credibility, or even reasonably full credibility, under current law." This can be taken to mean that he believed the maximum employment objective of the dual mandate was somehow a constraint on the FOMC's ability to achieve price stability, but he never said this explicitly.

Governor Yellen supported the bill's "focus on price stability as the single appropriate longterm goal of the FOMC" and endorsed the repeal of HH. Nevertheless, she had two "qualms" about the bill. First, she was concerned that the bill did not explicitly mention economic stabilization as a policy objective, saying that the bill seemed to suggest that "if we have just one tool of policy we cannot focus on more than one goal." She indicated that economic stabilization is an important goal in its own right and would remain important even when price stability was achieved. Echoing Blinder's comments, she suggested that the goals of price stability and economic stabilization may not always coincide:

I recognize that one could make the argument that the actions that are appropriate to stabilize output and employment are going to coincide with what one needs to do to stabilize the price level, namely, to lean against the wind. The problem is that the world is more complex than that, and these two objectives will not always go hand in hand. There are apt to be tradeoffs between the variability of output around its trend and the variability of inflation around a level of zero. That does not mean that I reject in any way the natural rate hypothesis. So, I think our policy ought to be directed to the pursuit of two goals, not one. $\underline{10}$

She also expressed concern that $\mathrm{HH}$ repealed an important portion of the Employment Act of 1946. 11 Specifically, she suggested that $\mathrm{HH}$ repealed the section of the Employment Act that "says in part that the government should 'use all practical means...for the purpose of creating and maintaining conditions which promote useful employment opportunities for those able, willing, and seeking to work." Wondering whether the Employment Act applied to the Federal Reserve, she noted that she had discovered a 1971 memo from the Board's general counsel, Howard Hackley, suggesting that it did. But she indicated that even if the act did not apply to the Federal Reserve, she "would oppose repeal of this feature of the Employment Act because it has implications for the federal government more broadly."

President Boehne supported the legislation, saying "In many ways the Mack bill conforms to how we have carried out policy in recent years." Noting that price stability is a means to an 
end, he argued that the Mack bill permitted the FOMC "to take into account short-run factors like fluctuations in demand, recessions, financial shocks, etc., but the short-run actions need to be anchored in this longer-run objective."

Echoing a view he expressed at the September 1995 FOMC meeting (p. 18), President Thomas Melzer of the St. Louis Fed noted

Don Kohn mentioned in his briefing that there was some ambiguity in the bill's language with respect to our taking into account the tradeoff between output and inflation. The way I read the language, it implied a tradeoff during the initial transition period. That is not an unimportant issue in terms of credibility. If that wording is read in effect as giving us latitude to engage in short-term fine-tuning on an ongoing basis, I think that is going to undercut our credibility and will remove some of the value that is inherent in an approach like this. $\underline{12}$

Blinder supported the long-run objective of the bill, saying

There is nothing whatever wrong about the phrase that says the "primary long-term goal" is price stability. In fact, it is one hundred percent right. That is what we do now. It's exactly correct, and I am perfectly happy with that in the law. You might even argue that it is the only long-term goal; I am not sure what else we can do in the long term.

However, he argued that policy should pursue other goals in the short run and preferred a bill that explicitly recognized the short-run trade-off, saying "I would like to see the ambiguity removed, as would Tom \{President Melzer\}, but in the opposite direction." $\underline{13}$

President Stern favored the legislation, suggesting that it "will get us toward our largest contribution to economic prosperity over time." However, he said he was uncomfortable with "virtually any hard-wired legislation that I can think of, even with legislation that is as flexible as this bill appears to be." He went on to note that the "good news" was that the bill eliminated what he termed "onerous provisions" of $\mathrm{HH}$, but he was concerned there could be a combination of "economic and possibly political circumstances that could inhibit us in the pursuit of an appropriate monetary policy if this legislation were in place." He was concerned the Committee could be in "a situation where we might have a law that we would have to ignore as we have ignored certain aspects of the Humphrey-Hawkins law for very good reasons." Unfortunately, he did not explicitly mention the requirements of $\mathrm{HH}$ that he believed were onerous or that the Committee had ignored.

President Thomas Hoenig of the Kansas City Fed expressed support for the "thrust" of the bill and "most of the specifics" and thought the bill provided the Committee with "flexibility in terms of the short-term effects of our policy and it gives us room to maneuver generally." However, echoing Governor Yellen's concern that at times the policy response could differ depending on whether the FOMC is trying to stabilize prices or output, he preferred having "specific language that takes into account supply shocks or other factors," indicating that he would be more comfortable with the legislation if it gave the Committee "a little more wiggle room in terms of policy actions that we might need to take in the short term."

President Cathy Minehan of the Boston Fed endorsed the bill's price stability objective, saying "like everyone else I think that the idea that price stability ought to be the long-term goal of the central bank is completely consistent with the contributions a central bank can make to eco- 


\section{Thornton}

nomic growth over the longer run." Nevertheless, she expressed concerns about what she termed the "autopilot aspects" of the legislation.

President Forrestal supported the bill, suggesting that "it is a vast improvement over Humphrey-Hawkins." Nevertheless, he too expressed concern that the bill "does not emphasize the other aspects of the central bank's responsibility, namely economic stabilization, to the extent that I would like."

President Michael Moskow of the Chicago Fed supported the "thrust" of the bill-that it "repeals the Humphrey-Hawkins bill." In contrast to the view of many of his colleagues, he said that the bill "is written about as well as we could expect it to be written." His only concern was Yellen's suggestion that it repealed the Employment Act of 1946; however, he confessed that "I haven't reread the Act, and I have to go back and reread it now since Governor Yellen raised this as a point."

President Jerry Jordan of the Cleveland Fed supported the legislation, suggesting that "the intent of Senator Mack and his co-sponsors is the very desirable goal of clarifying the role of economic policy and especially the role of monetary policy." However, he suggested that there was a fundamental difference between the model of appropriate monetary policy on which the Mack bill was based and the model of appropriate monetary policy that many of his colleagues on the Committee and of many of those who would testify about the desirability of the legislation:

Listening to some of this discussion...enhances my concerns about what will happen in the hearings. We will have a lot of very well respected, well-known academic, Wall Street, and other privatesector economists appearing before the Congressional committees. And instead of educating the members of the Senate and the House - and through them maybe the American public a littleabout the contribution that a stable currency can make toward the full employment goal of the Employment Act of 1946, they will speak mostly about the notion that stabilizing the value of the currency depends on maintaining a minimum army of unemployed, or maintaining slack, or holding growth below some notion of potential. As I read the legislation, I think it does not repeal the full employment goal of the Employment Act of 1946; in fact, the Mack bill clarifies that goal in very clear terms. It says in Section 2, Paragraph 8, that price stability is a key condition to maintaining the highest possible levels of productivity, real incomes, living standards, employment, and global competitiveness. Under the statement of policy, the bill says that an environment conducive to both long-term economic growth and increases in standards of living is fostered by establishing and maintaining free markets, low taxes, respect for private property, and the stable long-term purchasing power of the currency. So, I think that the intent of the legislative wording is that the contribution of monetary policy toward achieving the goals originally set out in the Employment Act almost fifty years ago is to stabilize the value of the currency. I simply am afraid that that is not what people would be hearing from a lot of our colleagues in the economics profession because they have a different model in mind. (Emphases added) $\underline{14}$

Governor Blinder responded to Jordan's comment, saying "To clarify what I said, if you read the fine print, there is a section in the bill that calls for the repeal of outmoded or obsolete provisions, or something like that. One of them is Section 2 of the Employment Act. That's why I said what I said." 15

President Bob McTeer of the Dallas Fed merely said, "I support the Mack Bill." President William McDonough of the New York Fed supported the bill but indicated that he "would like the bill to make it even more clear, although it does make it reasonably clear, that price stability is a means to an end." He suggested that "the single most important thing about the bill as proposed is probably that it repeals Humphrey-Hawkins." 
Echoing the views of many other Committee members, Governor Susan Phillips said

I generally support the thrust of the bill. I think that it is useful to clear out some of the clutter in the current Humphrey-Hawkins Act. One of the major positives of the bill is the clear focus on price stability and the purchasing power of our currency. But I, too, would like to see a recognition that this focus is not inconsistent with economic growth. In fact, this is how monetary policy specifically can contribute to economic growth.

Governor Lawrence Lindsey strongly supported the legislation, suggesting that while the Committee would prefer Congress "not give us instructions. That's not going to happen." He went on to indicate that he did not see how the Mack bill was tying the Committee's hands, saying

If we are allowed to define and redefine what we mean by price stability, what measure we are looking at, and over what time horizon we are focusing — and given that Congress will not go awayI think we have gotten the best deal that we can get.

In the discussion that followed, then-Board staffer Don Kohn followed up on Lindsey's point about flexibility, noting that when he spoke

to Hill staffers and asked them about this issue, one of the major points they make is that the Fed is defining price stability and defining the conditions under which you are getting there. Certainly, they would expect you to tell them if there is an adverse supply shock, so that getting there might be delayed. They viewed the provisions cited by Governor Lindsey as affording us flexibility...I think their view was that the Federal Reserve would have quite a bit of flexibility under this legislation, although they admitted that wasn't unambiguous.

Every Committee participant supported the idea that price stability is the primary, if not sole, long-run objective of monetary, reflecting (i) the Committee's view that inflation is the only thing that it can affect in the long run and (ii) the companion idea that price stability was how monetary policy promoted maximum output growth and employment in the long run. Moreover, eight Committee members (Blinder, Forrestal, Kelley, Lindsey, McDonough, Moskow, Phillips, and Yellen) explicitly expressed the desire to repeal HH. Unfortunately, none indicated the specific provisions of the $\mathrm{HH}$ that they thought were most troubling for the conduct of monetary policy. Only three members (Blinder, Moskow, and Yellen) explicitly mentioned employment in raising concerns about the Mack bill. On the whole, this discussion supports the language the Committee frequently used in explaining how it pursued the $\mathrm{HH}$ dual mandate and the language Greenspan sometimes used in his congressional testimony- "the Federal Reserve will pursue its statutory objectives of price stability and maximum sustainable employment-the latter of which we have learned can best be achieved in the long run by maintaining price stability." 16 Unfortunately, these discussions provide relatively little insight as to why the Committee did not mention employment or the unemployment rate in its policy statement until December 2008.

By the early 2000s core inflation measures declined to relatively low levels and remained relatively stable and references to the Fed's dual mandate increased. At the January 2002 meeting, Vice Chairman Roger Ferguson Jr. said 


\section{Thornton}

The fact that inflation appears to be under control currently and is likely to remain under control gives us a little more scope to look at the other side of the mandate-to foster maximum sustainable growth. $\underline{17}$

Governor Ferguson's statement appears to repudiate the notion that maximum sustainable growth is achieved by attaining price stability. Indeed, statements such as the FOMC can best achieve maximum sustainable output by stabilizing inflation virtually disappeared from the transcripts and, perhaps more tellingly, from the FOMC's policy statement. It is not clear whether this reflects a fundamental change in the Committee's belief in the long-run neutrality of monetary policy. It does, however, appear to reflect a belief that with inflation low and, perhaps more importantly, inflation expectations well anchored, policymakers can focus more on the objective of economic stabilization.

In any event, with inflation apparently under control and inflation expectations well anchored, many Committee members argued that monetary policy could be more aggressive in its pursuit of higher economic growth. The dual mandate was mentioned more frequently and there were more references to maximum employment; previously discussion had focused on economic growth. For example, at the January 2003 meeting, Governor Gramlich suggested "what is important is to clarify to markets what we care about. We care about stable prices and maximum employment."

At the May 2003 meeting, President Minehan suggested that "the degree of expected price decline and its implications for slack resource use are not ideal nor in my view consistent with our dual mandate." Noting that the decline in inflation had made monetary policy less accommodative, she suggested "It may be time now-and if not now, soon-to adjust policy so that it provides continuing support during this long, gradual recovery period." Governor Gramlich supported the idea that declining inflation provided an opportunity for a more accommodative policy but suggested that rather than easing policy immediately the Committee give itself "more time to organize our whole strategy in this new non-inflationary atmosphere."

Governor Gramlich addressed this issue specifically at the October 28, 2003, FOMC meeting, before which he had circulated a memo suggesting that the FOMC's policy statement be reworded to read

The probability that economic growth will proceed over the next few quarters at a rate consistent with the attainment of maximum sustainable employment is BELOW/EQUAL TO/ABOVE the probability of its falling short. Over the same period, the probability that inflation will be undesirably high is BELOW/EQUAL TO/ABOVE that it will be undesirably low.

At the start of the post-meeting discussion of the FOMC's communication policy, Gramlich asked permission to comment about his draft wording, noting that he was increasingly troubled that the FOMC's "assessments of the economy are not benchmarked." He suggested that the "phrase sustainable growth...could be associated with any unemployment rate" and indicated that his suggested language was an attempt to "put in benchmarks." $\underline{18}$

Greenspan responded immediately, saying

I think we have to be a little careful here because there is a prerequisite to this discussion that we don't talk about, namely how much can we rationally expect monetary policy to do. If we believe 
that monetary policy has the capability of affecting the economy incrementally in all sorts of waysto create whatever level of unemployment, GDP growth, and inflation we choose-and we can implement policies that will accomplish such objectives, then I can see announcing very explicit target levels. My problem with that type of policy commitment is that it promises far more than monetary policy has the capacity to deliver...If we say, for example, that our goal is to get the unemployment rate down to 4.6 percent with a growth rate in GDP that would close the output gap by $\mathrm{X}$ percent or something like that, that's all well and good. But do we actually have the capacity to accomplish that? My answer is that we most certainly do not.

Several members expressed concerns about being too explicit about the FOMC's policy goals. For example, Governor Ferguson preferred "to avoid language that is too precise in terms of specifying a variety of goals or targets...I'd be quite cautious about going too far down the path toward language that implies that we have specific targets or that forces us to continue to answer questions about what exactly our goals are or what we deem acceptable."

Most Committee participants thought a decision on a change in the language should be postponed until the Committee had more time to consider the issue. Governor Ben Bernanke said "I'm happy to wait until January if that's what people want to do," but expressed "a mild preference-more than a mild preference-for Governor Gramlich's formulation," noting that the

current statement and both of the suggested statements have benchmarks in the terms "sustainable growth," "unwelcome," "desirably lower," or "desirably higher." So that's not the question; all of the versions have benchmarks. I like Governor Gramlich's formulation better because his benchmark for output is not whether it is growing above or below the growth rate of potential but that it has a trajectory that leads eventually toward full employment. That is a different concept, but that's really what we should be shooting for. I think that's a better way of thinking about our objective. $\underline{19}$

Greenspan responding, saying "Where I have a problem with what you're saying is this. The notion that disinflation is unwelcome at this juncture is a value judgment all of us share. As I indicated to Ned \{Gramlich\}, if we all agree that the desirable level of unemployment is $\mathrm{X}$, then that's in the same category. If we can stipulate that we agree on the desirable level for every one of the goals, what you're suggesting can work. I'm basically saying that we're not going to achieve that." 20

President Broaddus expressed support for Gramlich's wording but indicated that the use of the employment benchmark is something that he would have to consider carefully. Governor Mark Olson expressed support for Gramlich's wording because "maximum sustainable employment and low inflation are our public policy mandate." Greenspan responded by saying "But he goes far beyond what you just said...He's trying to put in hard numbers or get something more conclusive than a vague notion of what is maximum sustainable growth. If we all agreed on what that number was, then we could do it. But that's not going to happen." Greenspan then asked Governor Gramlich if he was being misinterpreted. He responded that he thought so, to which Greenspan asked Gramlich to tell him where he was wrong. Gramlich responded: "All it says is that growth is proceeding at a rate that in our view is consistent with the eventual-and maybe we ought to put in the word 'eventual' - attainment of maximum sustainable employment. I don't think we have to say what that level of employment is, and I don't think we have to give an inflation target...I intentionally wrote it in a way that we could avoid giving specific numerical targets." Greenspan respond: "Well, the question is whether in fact in the real world that is capable 


\section{Thornton}

of being achieved." Gramlich agreed and Greenspan responded, "Okay, I withdraw my negative comment."리

President Moskow, the last to speak on Gramlich's suggestion, expressed concern about having a maximum sustainable employment objective in the policy statement even though they all agreed that that was the objective in the statute. He said

I find it difficult to envision a circumstance in which we would ever want to say publicly that economic growth will proceed over the next few quarters at a rate above that consistent with the attainment of maximum sustainable employment...I don't think we're ever going to want to say we're against more employment...I think the term "growth" has served us well over many years, and I personally like the term "growth" better here.

The FOMC considered several aspects of it communications strategy at its January 2004 meeting; however, none of these evolved into a statement about employment or the unemployment rate. $\underline{22}$ From time to time thereafter, discussions of the dual mandate arose. For example, at the August 2004 meeting, the policy directive included a final sentence that read, "Nonetheless, the Committee will respond to changes in economic prospects as needed to fulfill its obligation to maintain price stability." $\underline{23}$ Several members-Kohn, Ferguson, and Yellen-favored including sustainable growth in the final statement because, as Yellen put it, "I believe very strongly that we have a dual mandate, and that language reflects it." However, there was no discussion of including employment or the unemployment rate in the policy statement.

Greenspan reiterated his concerns about using employment rather than economic growth at the August meeting, noting

We are usually of the view that the employment data released on the first Friday of every month are the first real indication of economic activity that we see in that month. That was largely true when productivity growth was $1 \frac{1}{2}$ percent and it didn't vary all that much. Indeed, the hours figure was as good a proxy for real GDP as we could get. But when we have the wide variances of output per hour that we have been observing, we have to ask ourselves what, in fact, the employment data contribute to our estimate of actual GDP. In a technical sense, the answer is nothing.

\section{POLICYMAKERS' VIEW OF THE DUAL MANDATE: CONGRESSIONAL TESTIMONY}

The conclusion I derived from the congressional testimony of the Chairmen is, perhaps not surprisingly, the same as that obtained from reading the transcripts. Because the Chairmen were making the arguments, the arguments held more weight. The congressional testimony is particularly important for Chairman Volcker because he generally said little during the meetings.

Rather, he would summarize the consensus view of the Committee in making his recommendation. It is clear from his congressional testimony that Volcker's number one objective was to reduce the rate of inflation. He argued at various times that achieving the goals of rapid economic growth and high employment depended critically on restoring price stability. Volcker made the case for "inflation first" monetary policy dramatically in his February 1980 testimony, saying

In the past, at critical junctures for economic stabilization policy, we have usually been more preoccupied with the possibility of near-term weakness in economic activity or other objectives than 
with the implications of our actions for future inflation...As a consequence, fiscal and monetary policies alike too often have been prematurely or excessively stimulative or insufficiently restrictive. The result has been our now chronic inflationary problem.

Nor can we demonstrate that the result has been beneficial in terms of other objectives. To the contrary, unemployment has been higher in the 1970's than in earlier decades. Productivity growth has declined. Capital spending has not kept up with the needs of a growing labor force. Financial markets have been disturbed and depressed and institutions responsible for a substantial share of mortgage financing are coming under strain.

The recurrent weakness of the foreign exchange value of the dollar has undercut our economic stability at home and our leadership abroad.

The broad objective of policy must be to break that ominous pattern. That is why dealing with inflation has properly been elevated to a position of high national priority. Success will require that policy be consistently and persistently oriented to that end. $\underline{24}$

Throughout his term as Chairman, Volcker reiterated his view that success in achieving the other goals of monetary policy is conditional on achieving price stability. For example, in his February 1986 testimony, he suggested

We are convinced that sustained growth in the United States-and much more-is dependent upon maintaining progress toward price stability over time. And given our weight in the world, that same stability must be one of the foundation stones of a prosperous and integrated global economy.

Chairman Greenspan had a similar view. In his July 1988 testimony, he suggested that "The strategy for monetary policy needs to be centered on making further progress toward, and ultimately reaching, stable prices. Price stability is a prerequisite for achieving the maximum economic expansion consistent with a sustainable external balance and high employment." Greenspan repeated this theme frequently. As inflation decreased to levels that were more consistent with price stability, Greenspan seemed to place more emphasis on economic growth and employment in his testimony. For example, in his July 1994 testimony he suggested that the thrust of monetary policy was to foster "as much growth of output and employment as can be achieved without placing destabilizing inflationary pressures on productive resources." He went on to note, however, that "There is considerable uncertainty about what that goal implies for the expansion of GDP and rates of unemployment." However, he never wavered from what might be called a "price stability first" view of monetary policy:

- July 22, 1997: “Our objective has never been to contain inflation as an end in itself, but rather as a precondition for the highest possible long-run growth of output and income-the ultimate goal of macroeconomic policy."

- July 25, 2000: "Maximum sustainable growth, as history so amply demonstrates, requires price stability."

- February 17, 2005: “The Federal Reserve will pursue its statutory objectives of price stability and maximum sustainable employment, the latter of which we have learned can best be achieved in the long run by maintaining price stability.

This is the surest contribution that the Federal Reserve can make in fostering the economic prosperity and well-being of our nation and its people."

In his first two congressional testimonies, Chairman Bernanke echoed Greenspan's price stability first view: 


\section{Thornton}

- February 15, 2006: "Inflation prospects are important, not just because price stability is in itself desirable and part of the Federal Reserve's mandate from the Congress, but also because price stability is essential for strong and stable growth of output and employment."

- July 19, 2006: "In the long run, price stability is critical to achieving maximum employment and moderate long-term interest rates, the other parts of the congressional mandate."

However, Bernanke's subsequent statements placed greater emphasis on employment as a specific policy objective. Some examples follow:

- February 14, 2007: "My colleagues and I remain firmly committed to an open and transparent monetary policy process that enhances our ability to achieve our dual objectives of stable prices and maximum sustainable employment."

- July 18, 2007: "I take this opportunity to reiterate the Federal Reserve's strong support of the dual mandate; in pursuing maximum employment and price stability, monetary policy makes its greatest possible contribution to the general economic welfare."

- February 14, 2008: "A critical task for the Federal Reserve over the course of this year will be to assess whether the stance of monetary policy is properly calibrated to foster our mandated objectives of maximum employment and price stability." $\underline{25}$

As noted elsewhere (Thornton, 2011a), by the December 2008 meeting, the FOMC began stating its objectives in terms of "maximum employment and price stability."

\section{CONCLUSION}

The FOMC mentioned "maximum employment," the second part of its dual mandate required by $\mathrm{HH}$, for the first time in its December 2008 policy statement. Before that time, the Committee stated its dual mandate in terms of "maximum economic growth" or "maximum sustainable economic growth"; the latter phrasing was always taken to mean the economy's longrun or equilibrium growth rate achievable under stable prices. This article reviews the verbatim transcripts of FOMC meetings from 1978 through 2005 and HH congressional testimony in an attempt to better understand the FOMC's historical reluctance to state its dual mandate in terms of the language of the legislation that created it. Unfortunately, the transcripts do not provide a definitive explanation for this reticence.

It is certainly true that many FOMC members believed that the Committee could achieve its dual mandate by achieving the price stability objective. This outlook is consistent with that view that if all shocks are shocks to aggregate demand, then stabilizing output and employment is isomorphic (see, e.g., Thornton, 2003, 2009). It also holds true to Friedman-Phelps' natural rate hypothesis: that monetary policy cannot have a permanent effect on the equilibrium rate of unemployment. Indeed, the transcripts show virtually all Committee members accepted the natural rate hypothesis.

Greenspan expressed the greatest concern about stating an objective for employment growth or the unemployment rate beyond what was implied in the Committee's standard languagethat it was fostering a high rate of economic growth. He expressed concern that a specific statement about employment or the unemployment rate might promise more than monetary policy could deliver. Unfortunately, the transcripts do not reveal the prevalence of this view. 
The transcripts do reveal two shifts that may help explain the recent change in the language of the directive. The first is an increased emphasis on "economic stabilization." As inflation reached low levels and inflation expectations were considered anchored, the Committee became increasingly interested in pursuing short-run stabilization policy. This reflects one of the standard arguments for inflation targeting: Once inflation expectations are firmly anchored, monetary policy can become more countercyclical without fear that it will lose control over inflation.

The second shift was in emphasis from the growth rate of output to the level of output. This is best reflected in then-Governor Bernanke's statement that the "benchmark for output is not whether it is growing above or below the growth rate of potential but that it has a trajectory that leads eventually toward full employment." Output can be growing at a faster rate than potential while the level of output is still below potential; consequently, the economy is still not at full employment. Hence, the recent inclusion of employment growth and the unemployment rate in the FOMC's statement may not be as sudden as it appears. Rather, it may have been the result of (i) an evolutionary process associated with low and more-stable inflation, (ii) an increase in the number of Committee members who believe that monetary policy could do more to increase the level of output closer to potential so long as inflation remains low and inflation expectations are well anchored, and (iii) an increase in the number of academic economists on the Committee. Unfortunately, it is not clear whether the new emphasis reflects a change in the Committee's view about how and the extent to which monetary policy is capable of increasing the level of output beyond achieving price stability. This question is important because achieving price stability enhances economic growth by reducing or eliminating an important distortion from the market. On the other hand, countercyclical monetary policy affects economic growth and employment

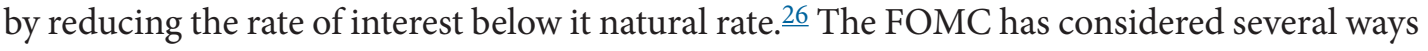
to become more transparent. One way is to explain the historical reluctance to state its policy objective in terms of employment or the unemployment rate and why it has only recently decided to do so.

\section{NOTES}

\footnotetext{
1 The full text of the act can be found at www.eric.ed.gov/PDFS/ED164974.pdf.

$\underline{2}$ For example, see Ljungqvist and Sargent (1998), Blanchard (2004), and Andofatto (2012).

$\underline{3}$ The FOMC transcripts, searchable by meeting date, are available on the website of the Board of Governors of the Federal Reserve System (www.federalreserve.gov/monetarypolicy/fomc historical.htm). Testimonies of Federal Reserve officials are also searchable by date (www.federalreserve.gov/newsevents/testimony/2011testimony.htm).

4 FOMC transcript, March 21, 1978, p. 37.

5 Note: The official Board transcripts use brackets to indicate any additions, so their original punctuation has been preserved. I use braces for any added clarifications.

$\underline{6}$ FOMC transcript, March 21, 1978, p. 38.

7 FOMC transcript, December 19, 1978, p. 53.

$\underline{8}$ FOMC transcript, January 31-February 1, 1995, p. 43.

9 FOMC transcript, September 26, 1995, p. 40.

10 FOMC transcript, September 26, 1995, p. 41.

11 FOMC transcript, September 26, 1995, p. 42.
} 


\section{Thornton}

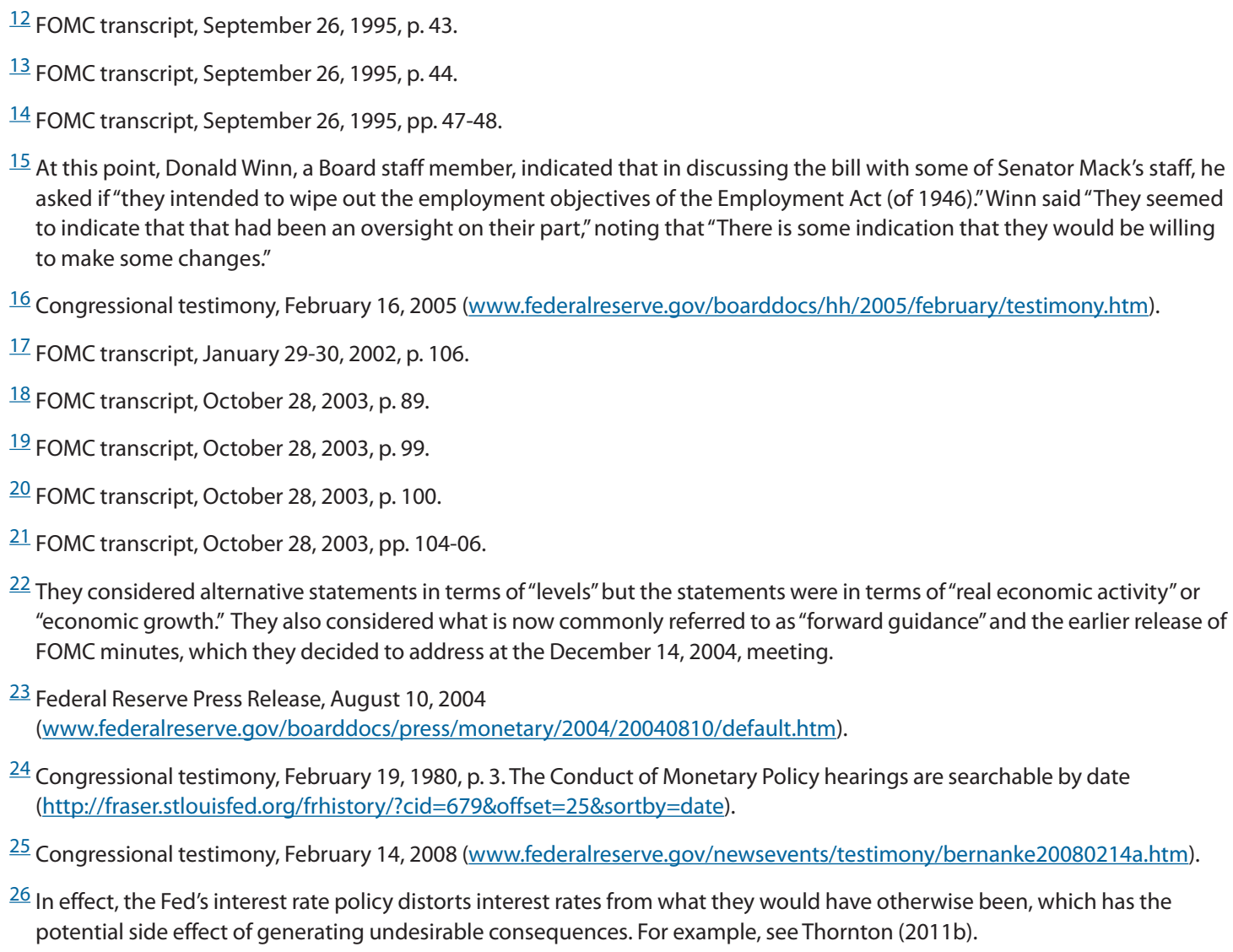

\section{REFERENCES}

Andofatto (2011). "Using Beveridge Curve Dynamics to Identify Cyclical and Structural Shocks." MacroMania (blog), January 24, 2012; http://andolfatto.blogspot.com/2012/01/using-beveridge-curve-dynamics-to.html.

Blanchard, Olivier J. “Explaining European Unemployment." NBER Reporter: Research Summary, Summer 2004; www.nber.org/reporter/summer04/blanchard.html.

Blinder, Alan S. "Overview," in Reducing Unemployment: Current Issues and Policy Options. Proceedings of the 2004 Jackson Hole Economic Policy Symposium, Jackson Hole, Wyoming, August 25-27, 1994; Kansas City, MO: Federal Reserve Bank of Kansas City, 2004; http://kansascityfed.org/publicat/sympos/1994/S94BLIND.PDF.

Daly, Mary and Hobijn, Bart. "Okun's Law and the Unemployment Surprise of 2009." Federal Reserve Bank of San Francisco Economic Letter, March 8, 2010; www.frbsf.org/publications/economics/letter/2010/el2010-07.pdf.

Friedman, Milton. "The Role of Monetary Policy." American Economic Review, March 1968, 58(1), pp. 1-17.

Knotek, Edward S. II. "How Useful Is Okun's Law?" Federal Reserve Bank of Kansas City Economic Review, Fourth Quarter 2007, pp. 73-103; www.kc.frb.org/publicat/econrev/PDF/4q07Knotek.pdf.

Ljungqvist, Lars and Sargent, Thomas J. "The European Unemployment Dilemma." Journal of Political Economy, June 1998, 106(3), pp. 514-50.

Meade, Ellen E. and Thornton, Daniel L. "The Phillips Curve and U.S. Monetary Policy: What the FOMC Transcripts Tell Us." Oxford Economic Papers, 2011, forthcoming.

Okun, Arthur M. "Potential GNP: Its Measurement and Significance," in Proceedings of the Business and Economic Statistics Section of the American Statistical Association. Alexandria, VA: American Statistical Association, 1962, pp. 89-104.

Phelps, Edmund S. "Money-Wage Dynamics and Labor Market Equilibrium." Journal of Political Economy, July/August 1968, 76(S4), pp. 678-711. 
Thornton, Daniel L. "Monetary Policy Transparency: Transparent about What?" The Manchester School, September 2003, 71(5), pp. 478-97.

Thornton, Daniel L. "The Case for 'Inflation First' Monetary Policy." Federal Reserve Bank of St. Louis Economic Synopses, December 18, 2009, No. 47; http://research.stlouisfed.org/publications/es/09/ES0947.pdf.

Thornton, Daniel L. "What Does the Change in the FOMC's Statement of Objectives Mean?" Federal Reserve Bank of St. Louis Economic Synopses, January 1, 2011a, No. 1; http://research.stlouisfed.org/publications/es/11/ES1101.pdf.

Thornton, Daniel L. "Is the FOMC's Policy Inflating Asset Prices?" Federal Reserve Bank of St. Louis Economic Synopses, June 24, 2011b, No. 18; http://research.stlouisfed.org/publications/es/11/ES1118.pdf. 


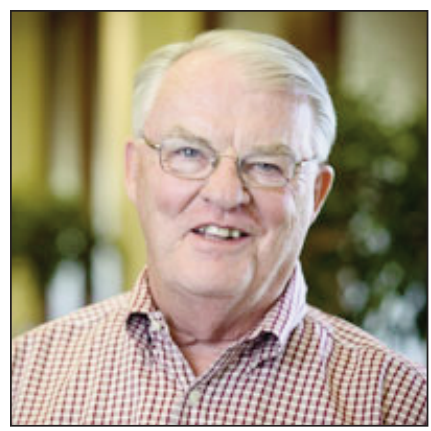

\section{Daniel L. Thornton}

Vice president and economic adviser, Federal Reserve Bank of St. Louis

http://research.stlouisfed.org/econ/thornton/

\section{Research Focus}

Dan Thornton analyzes financial markets, interest rates, and monetary policymost recently, the Fed's policy innovations of quantitative easing and the Term Auction Facility in the wake of the financial crisis.

\section{Recent Research}

"The Effectiveness of Unconventional Monetary Policy: The Term Auction Facility." Federal Reserve Bank of St. Louis Review, November/December 2011, 93(6), pp. 439-54.

"The FOMC's Interest Rate Policy: How Long Is the Long Run?" Federal Reserve Bank of St. Louis Economic Synopses, 2011, No. 29.

"A Perspective on Financial Market Reform,, International Center for Banking and Corporate Governance, 2010.

"The Unusual Behavior of the Federal Funds Rate and Treasury Yields: A Conundrum or an Instance of Goodhart's Law?" Federal Reserve Bank of St. Louis Working Paper 2007-039C, updated August 2010. 